\title{
"GOOD WHILE IT LASTS": INTERNATIONAL ALLIANCES BETWEEN BRAZILIAN FAMILY FIRMS AND FOREIGN FIRMS
}

\author{
Álvaro Luiz dos Santos Werneck, Ângela da Rocha ${ }^{1}$ \\ Pontifícia Universidade Católica do Rio de Janeiro - PUC, Rio de Janeiro, (Brasil).
}

\section{ARTICLE DETAILS}

Article history:

Received: 26 September 2018

Accepted: 03 June 2019

Available online August: 01 th 2019

Double Blind Review System

Scientific Editor

Ilan Avrichir

Keywords

Alliances

Partnerships

Cooperative Strategies

\section{ABSTRACT}

The study aimed at investigating how Brazilian family firms internationalize by means of strategic alliances with foreign corporations. A literature review on strategic alliances and the internationalization of family firms served as the basis for the study, which uses the case method of investigation. Two cases involving marketing alliances between Brazilian family firms and foreign firms were analyzed. The study presents an empirically-derived framework of the processes of establishing, developing, and (eventually) terminating these strategic alliances, indicating potential hazards (asymmetries of size, information, and resources) that can impact the results, particularly within a context of different cultural background of the partners.

\section{Introduction}

Brenes, Madrigal and Requena (2011, p.280) define a family business plainly as "a company in which ownership and management are carried out mostly by a single family." According to the Brazilian Institute of Corporate Governance (IBGC, 2016), family or multifamily control can assume two forms: defined and diffuse. A firm has defined control when one shareholder or a group of them bound by a common agreement, holds more than $50 \%$ of the voting shares. On the other hand, a firm's control is considered diffuse when it is "exercised by a partner or group of partners that is not bound by a partnership agreement, does not retain control or does not represent a common interest, and holds a significant but less than $50 \%$ portion of the voting capital, in which one or more families retain the power of control" (IBGC, 2016, p. 9).

The economic importance of family firms is undisputable. In a study conducted by Sebrae (2015) in Brazil, $57 \%$ of small formal businesses were identified as family-owned. In the global arena, a study by the multinational consulting firm PwC (2016) revealed that family firms in the world generate around $25 \%$ of their revenues from exports, compared with an average of $8 \%$ in Brazil. Kontinen \& Ojala (2010) state that in spite of the importance of family firms, the internationalization of such firms is still a new field with limited knowledge available. Therefore, these authors claim that more research is needed, and they recommend a more frequent use of case studies to investigate the internationalization of family firms.

In addition, a systematic literature review (MarínAnglada, Campa-Planas \& Hernández-Lara, 2014) listed only 92 articles published between 1991 and 2012 related to the internationalization of family firms. In fact, only 12 articles were identified in the 1991-2000 period, compared to 80 during 20012012 , suggesting an increase in scholarly interest in the topic. Interestingly, a bibliometric review of articles on entrepreneurship and family firms (LópezFernández, Serrano-Bedia \& Pérez-Pérez, 2016), covering the period 1992-2011, mentions only one article (out of 129 examined) that addresses the process of internationalization of family firms, and 
two that address the issue of opportunity recognition in an international context.

The present study focuses on one specific entry mode - international marketing alliances - which often appears in the initial steps of a firm's internationalization. Beamish and Lupton (2016) emphasize the growing importance of strategic alliances over the past fifty years. Globalization has increased the degree of economic openness and the number of market transactions, thus stimulating cross-border activities. Alliances can be an extremely valuable mode for entering a foreign market because they have the potential of lowering transaction costs (Gomes, Barnes \& Mahmood, 2016). Firms also adopt international strategic alliances due to the difficulty of operating alone, as they need to perform multiple functions in the international market (Mehta et al., 2006).

Faced with an increasingly competitive scenario in their domestic markets, family firms are often forced to consider internationalization as a means of firm growth and survival. In fact, Lee et al. (2012) show that the internationalization of small and mediumsized enterprises (SMEs) can increase their probability of survival. While internationalization can increase the complexity of their operations, it can also be an opportunity to learn to compete with large companies that may face the same challenge of entering a still-unfamiliar foreign market and transfer this knowledge to the domestic market. In their efforts to go international, family firms may find in international partners the resources and capabilities to keep ahead of competitors and achieve better performance. Seeking international partners, identifying foreign opportunities in strategic alliances, recognizing existing barriers, and adopting new paths to achieve better performance are thus important challenges for family firm managers.

The applicability of these research results to emerging market family firms, particularly small and medium-sized firms, however, is not established in the literature. In fact, the bulk of the literature on family firms comes from developed countries, and few studies have looked at emerging market family firms. Ray, Mondal and Ramachandran (2018, p.75) note, for example, that there has been a recent call for "studies on the internationalization of family firms rooted in underexplored, yet unique institutional contexts", which would much contribute to the understanding of the phenomenon. This is the case of studies on Latin America and, specifically, Brazil. Studies on the internationalization of family firms in Brazil are still scarce, with a few notable exceptions (Oliveira, Albuquerque \& Pereira, 2012; Segalis \& Guedes, 2012), but none looked specifically at the choice of entry mode by family firms in their international expansion.

The present study thus contributes to the growing literature on strategic alliances between domestic family firms from an emerging economy and international firms. The following research question guided the study: How do Brazilian family firms internationalize using strategic marketing alliances with foreign firms? To answer this question, the paper proceeds as follows: after this introduction, we present the theoretical background used in the study, followed by the research methodology adopted. Then, we present and discuss two cases of strategic alliances between Brazilian family businesses and foreign firms. Finally, we draw our conclusions and recommendations for managers and for future research.

\section{The Internationalization of Family Firms}

The last two decades saw a growing scholarly interest concerning the internationalization of family firms. However, the research results are often contradictory. For example, studies on the relationship between internationalization and family control sometimes show positive results, other times negative results, or even the relationship is found to be nonsignificant (Ray, Mondal, \& Ramachandran, 2018). Thus, the evidence is not clear regarding whether a family firm differs from their counterparts (non-family firms) in terms of their propensity to internationalize.

The literature presents several factors that may increase or reduce the probability of a family firm's internationalization. Some factors may act as obstacles to the international expansion of family firms, such as risk aversion and preference for the domestic market. However, the increase in global competition and low growth in domestic markets have led family firms to overcome their preference for domestic markets and seek internationalization (Kontinen \& Ojala, 2010; Patel, Pieper \& Hair, 2012). Risk aversion tends to be a major barrier to a family firm's internationalization due to the need to preserve socioemotional wealth and to prevent family conflicts (Patel, Pieper \& Hair, 2012). Another factor is the lack of resources to invest in 
"Good While It Lasts": International Alliances Between Brazilian Family Firms And Foreign Firms

international expansion due to family firms' "wellknown reluctance to dilute ownership" (De Massis, Frattini, Majocchi \& Piscitello, 2018, p.5). In addition, when going international, family firm owners seek to maximize sales in markets with which they have more affinity rather than actively pursuing new opportunities in whatever countries in the world they may appear. In general, these businesses tend to adopt family-oriented rather than market-oriented strategies (Kontinen \& Ojala, 2010). Pukall and Calabrò's (2014) literature review indicates that $100 \%$ family ownership has a negative relationship with internationalization. Nevertheless, Sciascia et al. (2012) show that export intensity increases when there are also other shareholders with significant stakes in the firm, and Dou et al. (2019) indicate that the experience of members of the board and the involvement of younger family members in the firm's decision-making process has a positive impact on internationalization.

On the other hand, there are a couple of characteristics that may increase the probability of a family firm going international (Patel, Pieper, \& Hair, 2012; Kontinen \& Ojala, 2010). First, because the decision process is usually more informal and agiler than in a typical corporation, family firms may move faster than their counterparts. Second, family firms often have access to certain low-cost resources, such as the entrepreneurial capabilities of family members and family wealth.

In fact, family firms prefer to use family resources in order to avoid debt or the selling of company shares to outsiders. Figure 1 summarizes Patel, Pieper and Hair's (2012) factors impacting family firms' internationalization.

\section{Tables and Figures}

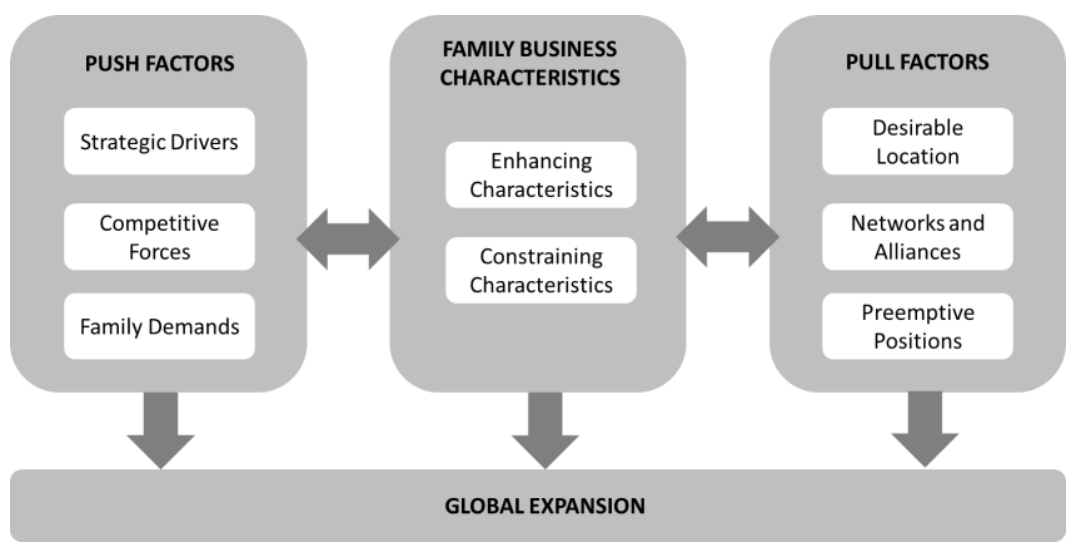

Figure 1: Pressure and attraction factors for family business expansion decisions Source: Patel et al., 2012, adapted from Etemad (2004, p. 5)

The literature has given scant attention to the choice of foreign entry mode by family firms. In a literature review of the internationalization of family firms, covering the period between 1980 and 2012, Pukall and Calabrò (2014) found that these firms show a preference for exporting as a mode for entering foreign markets. Family firms also have a greater propensity to invest locally, which interferes negatively with their foreign direct investment decisions.

Moreover, family firms avoid entry modes that impact their independence, such as strategic alliances, but this aversion is mitigated if the partner is another family firm (Pukall \& Calabrò, 2014). In spite of this, Patel, Pieper and Hair (2012) argue that family firms show a preference for long-term commitments and for relationships based on trust, which, in turn, tend to ensure the longevity of partnerships and alliances. The authors also point out that these firms often use their family networks, including family members that live in another country, or members of their extended family. Also, studying family firms in Japan, Yamanoi and Asaba (2018) find a preference for greenfield investments and full ownership. However, these characteristics may be specific of Japanese family firms and not generalizable to other countries' firms.

In fact, a growing concern among scholars interested in the internationalization of family firms is their heterogeneity, which can explain, at least to some extent, inconsistencies in the research results (Arregle, Duran, Hitt, \& Essen, 2017; De Massis et al., 
2018; Ray, Mondal, \& Ramachandran, 2018). For example, family firms may differ in terms of home country, size, ownership patterns (privately-held or publicly-held; participation of institutional investors), board composition (family members only, or mixed), access to international capital markets, type of management (family and/or professional), generation in power (founders or subsequent generations), among many other aspects. Such aspects may influence the choice of entry mode by family firms, particularly when it comes to the country-of-origin of the firm, which is a proxy for level of economic development, cultural aspects, and nature of institutions, among others. In fact the heterogeneity of family firms is a challenge for any generalizations across different countries and cultures.

\section{The Establishment and Maintenance of Strategic Alliances}

The present study adopts Christoffersen's (2013, p.69) definition of international strategic alliances as "collaborations involving the long-term commitment of resources to relationships that serve the strategic goals of two or more partners based in different countries, or whose collaborative operations take place in a different country to their headquarters." There is, however, substantial disagreement among scholars as to what types of arrangements can be considered strategic alliances. For example, Varadarajan and Cunningham (1995) do not consider the relationship between a third-party and a buyer to be a strategic alliance. From their perspective, the purpose of a strategic alliance will only be reached if it offers a strategic, competitive and sustainable advantage (Varadarajan \& Cunningham, 1995). Alternatively, Beamish and Lupton (2016) argue that, regardless of whether these activities are equitybased or not, most types of cross-border cooperation consist of international alliances. In the same vein, De Wit \& Meyer (2004) consider three types of strategic alliances: non-contractual, contractual, and equitybased.

Marketing alliances are a common form of strategic partnering, with the potential to increase the firm's value (Swaminathan \& Moorman, 2009). There are several types of alliances in marketing, such as the use of co-branding, joint sales force, or joint promotion, none of which require the creation of a joint venture or the implementation of mergers and acquisitions, but which do make it possible to gain market share and new clients and, at the same time, retain flexibility. Marketing alliances also alow to combine different firm resources and marketing capabilities (Yu, Gilbert \& Oviatt, 2011). International strategic alliances related to distribution channels aim at building long-term cooperative relationships. The management of such alliances, however, is quite complex, especially when the alliance is not a legal entity with well-established norms and authority (Mehta et al., 2006).

By implementing strategic alliances, companies intend to achieve growth in sales, increase in market share, or increase in profits by means of a relationship based on mutual satisfaction with the partner (Mehta et al., 2006). According to the VRIO model (Barney \& Hesterly, 2011), for a strategic alliance to be competitive and sustainable, it must give the partners access to valuable, rare and difficult to imitate resources and capabilities, thus permitting to exploit opportunities and avoid threats. Successful strategic alliances are also based on personal relationships, where trust and empathy between the partners are of great value and where it is not possible to imitate a specific social relationship. An alliance with a high level of trust between the partners allows both firms to maintain their independent visions, although objectives or actions may overlap (Beamish \& Lupton, 2016).

A major issue that has stimulated considerable debate in the extant literature has to do with the dissimilarities between the partners in an international strategic alliance. Christoffersen (2013) summarizes the differences encountered in the literature in terms of size, cultural distance (national and organizational), and experience (international experience, experience in alliances, previous relationship with the partner). In general, experience has a positive impact on alliance performance, whereas cultural distance has a negative impact. As for the impact of differences in size, there is no agreement among scholars, although the most common position is that size dissimilarities may create information asymmetries (Doz, 1988), which, in turn, may increase the risk of opportunistic behavior (Beamish \& Jung, 2005).

Situations of dominance of one partner over another are possible in a strategic alliance (Christoffersen, 2013). One situation involves control by the dominant partner, which may have a positive aspect if it simplifies the relationship between the partners, but it may have a negative aspect if it leads 
"Good While It Lasts": International Alliances Between Brazilian Family Firms And Foreign Firms

to conflict and frustration for one of the partners. A second possible situation is dominant control exercised by a foreign partner, particularly in alliances involving firms from developing and developed countries. Lastly, a third situation may arise when a focal partner dominates the relationship, if that partner possesses resources and capabilities to which the other partner does not have direct access.

With regard to small and medium-sized enterprises, which include a large proportion of family firms, Musteen and Datta (2011) highlight the importance of relationship networks for overcoming the difficulties involved in entering new international markets. However, establishing and maintaining strategic alliances is not an easy process, since it requires substantial efforts by the firms' managers and takes a long time, particularly when dealing with lengthy and difficult negotiations between individuals and firms from different cultural contexts. For example, Arranz, Arroyabe, and De Arroyabe (2016) show that the alliance-building process, with its inherent complexity, negatively impacts the intention to establish an alliance by SMEs. Finally, Tiwari, Sen and Shaik (2016) suggest that small and mediumsized emerging market firms use strategic alliances to entering foreign markets and thus complementing their resources and capabilities with those of their foreign partners.

\section{Methodology}

The study uses the case method of investigation, which is considered one of the most frequently used qualitative research strategies in international business (Ghauri, 2004) and "a key research strategy in the field" (Piekkari \& Welch, 2011, p. 3). Additionally, a large portion of the research on strategic alliances uses case studies "given the rich context afforded by international alliances" (Beamish \& Lupton, 2016, p.168).

The unit of analysis is the strategic alliance. The criteria for case selection were: first, the Brazilian partners had to be family firms; second, their foreign partners had to be international firms; and third, they had to agree to give interviews to the researchers. Two cases were selected. The first case was Eco Orbis, a small company, which, for ten years, was the commercial arm in Brazil for Germania Fairs, a large German company operating in the events industry. This alliance began in 2002 and ended in 2011. The names of the two companies have been changed herein. The second case involved Granado, a Brazilian family firm in the cosmetics and fragrance industry. The period analyzed was between 2012 and 2016, when Granado held an international alliance in marketing and sales with the French department store Le Bon Marché (part of the LVMH group).

Interviews were conducted with senior managers and family members of the two Brazilian organizations. Two interviews were conducted with the CEO (owner-manager) at Eco Orbis and two interviews - with the sales manager and with the marketing manager (also a family member) - at Granado, during 2017. Each interview took around one hour. Only the interviews with Granado were recorded and transcribed; the other firm preferred not to have the interviews recorded. However, one of the researchers took detailed notes during these interviews. Aspects that needed clarification were solved later by email and telephone. The foreign partners were not interviewed. Therefore, the cases show the perspective of only one of the alliance partners - the Brazilian firm. Information about the companies was also collected on the Internet by searching online business magazines and newspapers from the countries of origin (Brazil, France, and Germany), as well as the institutional website of each company. The use of different sources allowed triangulation. The results were analyzed using case description, cross-case analysis, and comparison with the theoretical patterns identified in the literature review (pattern-matching analysis) (Ghauri, 2004; Yin, 2015).

\section{The Alliance between Eco Orbis and Germania Fairs}

Eco Orbis was created in 2001 by three partners: two relatives and a third partner, considered part of the extended family, which saw a business opportunity in the sustainable products market. In 2001, they developed a website that became wellknown in the area of organic and health foods in Brazil. With an English version, the website was quite successful at a time when there were few similar sites on the Internet. In 2002, Germania Fairs, a German company specializing in fairs and exhibitions, approached Eco Orbis using a consultant specializing in the organic food market. Germania Fairs is the international division of a German company that organizes fairs, with more than 400 employees at its headquarters in Germany. In 2011, its overall turnover was around 200 million Euros. The company is not family-owned. Germania Fairs invited Eco Orbis to visit EkoFair, one of the largest organic food events 
in the world. The German firm was interested in having an annual edition of the fair in Brazil, as part of a larger internationalization plan. The project would be financed by means of a public-private partnership supported by a German development bank. Eco Orbis' management traveled to Germany to participate in EkoFair 2002 with the purpose of negotiating the project. The deal was sealed and the project was carried out over the next two and half years. The idea was to hold the event in Rio de Janeiro in 2005.

Once the public-private partnership between Germania Fairs and the German development bank was set, the collaboration between Eco Orbis and Germania Fairs was formalized through a cooperation agreement drawn up by the German company and reviewed by the Brazilian company. With respect to the organization of EkoFair in Brazil, which was the main source for the revenue resulting from the partnership, Eco Orbis would be responsible for organizing and administrating the fair, including marketing it in Latin America, while Germania Fairs would be in charge of promoting it internationally. At the end of each edition in Brazil, the documentation regarding costs and revenues of the event was to be sent to Germany.

Small workshops were then held in twelve Brazilian states in preparation for the fair. EkoFair Brazil exceeded the expectations of the organizers, with more than 800 participants. The administrative work was carried out by the Brazilian team; the German company provided the internationallyrenowned brand and used its extensive network of contacts to publicize the event. The seminars continued in 2004, this time with the expansion of the project to other countries in Latin America.

EkoFair Brasil 2005 was held in the largest exhibition center of the city of Rio de Janeiro and in the city of São Paulo in the following years. As the organic food market developed, the fair grew slowly but steadily, showing year after year an increase in the number of exhibitors, as well as in the number of visitors. For example, the 2007 edition had 311 exhibitors, of which $77 \%$ were from Brazil and $23 \%$ from foreign countries - mainly Latin American (e.g. Peru, Argentina, Bolivia, and Ecuador) - and Germany. The planning for the next edition began at the end of each fair, taking advantage of the presence of representatives from Germania Fairs in Brazil. After the last day of the event, organizers from both countries met to make a brief overall evaluation of the event. Another form of cooperation between Germania Fairs and Eco Orbis included the representation of other global fairs. To this end, there was a specific contract. The sale of Latin American booths was to be conducted by Eco Orbis, while the sale in other regions was to be conducted by Germania Fairs.

However, Eco Orbis' managers did not perceive the same commitment on the German side that they believed they themselves had. While the Brazilian company received a large portion of its annual turnover from the alliance, these activities were not as important to the German partners due to the dozens of fairs that it held throughout the world. Nevertheless, the managerial team at Eco Orbis believed there was a friendly, although not profound, relationship with the president of Germania Fairs and with its representative in Brazil.

However, at the end of 2008, disturbing news reached the managers of Eco Orbis. Germania Fairs had acquired a Brazilian company established in São Paulo. The acquired company was much larger than Eco Orbis, with around 40 employees, and had already held large fairs in the city of São Paulo. In 2008, the acquired company was renamed Germania Fairs Brasil (GFB) and officially became the Brazilian subsidiary of the German company. Eco Orbis' owners were quite disturbed. They learned that the negotiations for the acquisition of the São Paulobased firm had taken at least one year, without any information being passed to Eco Orbis by the German partner.

Since there was an ongoing contract between Eco Orbis and Germania Fairs, the new arrangement was that Eco Orbis would be directly connected to the newly-established subsidiary in Brazil. From then on, Germania Fairs let the alliance be managed by the Brazilian subsidiary, and did not participate directly in local negotiations. A new division of responsibilities was negotiated: the commercial activities remained with Eco Orbis and the operational and administrative management with GFB.

However, this arrangement soon failed, since GFB started to establish business contacts with some of the main supporters of EkoFair Brazil. In the view of Eco Orbis' owners, it became clear that GFB's management wanted to absorb the EkoFair Brazil business into its own structure. The company's owners thus decided to terminate the alliance with 
"Good While It Lasts": International Alliances Between Brazilian Family Firms And Foreign Firms

Germania Fairs. The alliance between the two companies was contractually ended in 2011.

\section{The Alliance between Casa Granado and Le Bon Marché}

Casa Granado's history began in 1870, when it was founded by the Portuguese businessman José Antonio Granado in the city of Rio de Janeiro. Working with cosmetics and perfumery, the company soon became an official supplier to the Brazilian imperial family. After three generations of the Granado family in the ownership and management of the firm, Christopher Freeman, an Englishman, acquired the company in 1994 for eight million dollars. His daughter, Sissi Freeman, became responsible for the company's marketing activities.

In 2011, Granado was a medium-sized domestic company, with a turnover of around 50 million dollars. In 2016, the company had 45 stores and a market value of 1.5 billion dollars (Exame, 2016). As the competition in the Brazilian market started to intensify, with several acquisitions of domestic family firms by multinational corporations, Freeman started to look for a minority partner, aiming at strengthening the company and supporting its internationalization. After negotiations, the Catalan group Puig acquired 35\% of Casa Granado. Puig, founded in 1914, was a traditional family conglomerate in the global perfumery and fashion industry (including international brands such as Paco Rabanne, Nina Ricci, and Jean-Paul Gautier), based in Barcelona, Spain, and with operations in 150 countries. Puig's products were considered complementary to those of Granado, and therefore there was no direct competition. Due to the experience of the Catalan group, Granado's management team indicated that it valued its partner's advice, especially because of its international experience. Granado's owners felt that they shared values and a long-term vision with Puig because it too was family-owned.

In 2012, Casa Granado had the opportunity to start its internationalization process. The firm was invited to take part in the Rive Gauche Campaign of the traditional Parisian department store Le Bon Marché (LBM). Founded in 1852, Le Bon Marché was also a long-established firm in the retailing industry. In 1877, the department store already had more than 1,700 employees. The firm went through different succession processes and periods of expansion in the following decades. In 1984, Financière Agache, controlled by Bernard Arnault, acquired the firm, focusing on luxury products and adopting an upscale stance (Gernier, 2011). Currently, LBM is part of the LVMH group, in which Bernard Arnault is also a partner. The alliance with LBM opened a new phase in the development of Granado's activities in foreign markets. Granado's sales manager was responsible for developing the alliance with LBM, as well as managing the internationalization process.

The alliance with LBM began in 2012. The following year, LBM honored Brazil in an annual event, just one year before the World Cup in the country. The company had been looking for Brazilian brands to participate in this promotion, and Granado was the only cosmetics brand to be invited. The initial plan was that all products would be displayed for three months. However, Granado considered this period to be too short. In fact, the promotion of cosmetics is much more complex than that of fashion. While clothes can be sent back to the home country if they are not sold, cosmetics cannot, because they have an expiration date. In addition, cosmetic products have to comply with local regulations, requiring some investment by the exporting company. After a negotiation between the partners, LBM agreed that the Granado brand would become part of the store's regular assortment. In return, LBM would be granted exclusive rights (for department stores) to sell the Granado brand in Paris. Granado also made additional requests. For example, LBM would build the furniture for the cosmetics exhibition; Granado would not pay space rent, and LBM would be in charge of local public relations.

Granado's internationalization strategy envisaged expanding with its own stores in Europe, similar to what it had done in Brazil. Product development was considered the heart of the international strategy. Granado's products are well differentiated in Europe because they are "made in Brazil," benefitting from the country's exotic and tropical image. In addition, they are "free of," that is, without ingredients considered harmful, which is a trend in Europe. Granado expanded its activities in Paris to other channels of distribution, but always with the consent of LBM. In addition, the firm opened points of sale in London and Lisbon. In 2017, Granado opened its own store in Paris. The choice of starting its own chain in Paris was made because the products were already labeled in French. Granado's management intended to open stores in other cities in France, Belgium and Portugal, since the firm already had labels in French and Portuguese. By the time of the interviews, sales 
to LBM were still quite small in relation to Granado's total turnover.

Granado's management team felt that the firm's international expansion was made possible by the presence of the brand in LBM, an upscale department store. Such a marketing alliance provided status, recognition, and visibility, and it positioned Granado as a premium brand. Furthermore, the brand association also had a positive impact on Brazilian buyers. Lastly, the profit margin of the international operation enabled it not only to compete with similar brands in the foreign market, but also to invest in marketing and to open stores. When asked about the limits of the alliance, the sales manager pointed out that the relationship between Granado and the Louis Vuitton group is an open one. The alliance is seen as very positive, but Granado intends to have its own distribution chain in Europe, a possibility that has been openly discussed with LBM.

\section{Discussion}

The two cases examined in this study are contrasting examples (Yin, 2015). The Brazilian partners in each alliance differ in firm size and age, although both are domestic family firms. In both cases the potential foreign buyer initiated the contact with the Brazilian firm, but also in both cases management recognized and exploited the opportunity. Interestingly, the extant literature gives a lot of attention to the partner's selection in strategic alliances (e.g. Beamish \& Lupton, 2016), but often omits the fact that usually one of the partners (typically, the local partner) does not have access to this option.

Therefore, in this study, we adopted the perspective of the local partner to examine the alliance. The following discussion is organized by themes in the alliance development process.

\section{Pre-alliance contacts}

Although the firms' owners did not have a preestablished plan to internationalize, they seemed to follow the effectuation logic (Saravasthy, 2001), that is, the opportunities appeared and management recognized and exploited them. Nevertheless, although there were no pre-existing strategic goals, the owner-managers were motivated to pursue the alliances.

According to the literature, the main reasons why family firms develop strategic alliances are to increase sales and profits, improve cash flow, increase market share and, consequently, firm value, by sharing resources and capabilities with partners, or even with the expectation of reducing uncertainty and risk (e.g. Kontinen \& Ojala, 2010; Pukall \& Calabrò, 2014; Swaminathan \& Moorman, 2009). These possibilities were taken into consideration by the Brazilian partners in each alliance. Eco Orbis, the Brazilian partner in the first case, was a nascent firm in search of a profitable product, but which had specific capabilities that attracted the partner. The owner-managers saw the opportunity for growth that the alliance could bring. Eco Orbis also had the potential to compete in the national market because of its alliance with Germania Fairs. Therefore, despite being a small company, Eco Orbis could compete side by side with large companies (Lee et al., 2012), some of them national event organizers in the Brazilian market. Additionally, the alliance with Germania Fairs provided the opportunity to enter the Latin American market, thus expanding the international scope of Eco Orbis.

As for the second case, Casa Granado, the firm was already solidly established in the domestic market, with almost 150 years of existence. The family that had acquired the business from the original family not only had revitalized it but had also expanded its geographic scope within Brazil. Granado's owner-manager was interested in growth, profitability and firm value, but he also considered risk reduction as an important outcome of internationalization, and the strategic alliance as a trigger for internationalization. In fact, since Brazil had been in a deep recession since 2014, Freeman believed that internationalization was a solid strategy for reducing the risk of operating in only one country.

\section{Closing the Deal}

A contractual agreement was signed between the alliance partners in the two cases examined. Both contracts had a fixed term, but there was on the Brazilian side the expectation of establishing a medium- to long-term trust-based relationship, as predicted in the literature (e.g. Patel, Pieper \& Hair, 2012). However, size differences may bring information asymmetries into the relationship (Beamish \& Jung, 2005).

This was apparent in the case of Eco Orbis, whose contractual agreement with Germania Fairs was drawn up by the German partner and agreed on by the Brazilian firm. The alliances were expected to bring benefits to both partners (Table 1). 
Table 1: Expected benefits of strategic alliances for the partners

\begin{tabular}{|l|l|}
\hline \multicolumn{1}{|c|}{ Eco Orbis $\leftrightarrow$ Germania Fairs } & \multicolumn{1}{c|}{ Granado $\leftrightarrow$ Le Bon Marché } \\
\hline $\begin{array}{l}\text { Germania Fairs owned the brand of the most } \\
\text { important fair in the world in the area of organic food } \\
\text { and was interested in entering the Latin American } \\
\text { market, particularly Brazil. }\end{array}$ & $\begin{array}{l}\text { Le Bon Marché (LBM) was a traditional department } \\
\text { store with more than a century of existence and upscale } \\
\text { positioning, and was seeking differentiation by adding } \\
\text { interesting, exotic products. }\end{array}$ \\
$\begin{array}{l}\text { Eco Orbis was known in Brazil for information and } \\
\text { contacts in this industry and was looking for a new } \\
\text { product to accelerate growth. }\end{array}$ & $\begin{array}{l}\text { Granado was also a centennial brand wanting to } \\
\text { internationalize, offering differentiated products in the } \\
\end{array}$ \\
\hline
\end{tabular}

\section{Building and Strengthening the Relationship}

Relationship development is a major topic in the internationalization process literature (Johanson \& Vahlne, 2009, 2013) and in the strategic alliance literature (Kontinen \& Ojala, 2010). Both with Granado and with Eco Orbis, the main driver for the continuance of the alliance and the evaluation of its success was trust, a factor considered of major importance for the performance of international alliances (Beamish \& Lupton, 2016; Christoffersen, 2013). Thus, part of the success of the alliance between Eco Orbis and Germania Fairs in the early years, and of that between Granado and LBM, can be credited to the relationship of trust and transparency between the partners.

As the relationship developed, in the case of Eco Orbis, new attributions were delegated to the Brazilian partner, which convinced the firm's managers about the success of the alliance. Traveling to and from the partner's country was another way of developing the relationship. And despite Eco Orbis' small size and the existence of a company representative in Brazil, the Brazilian ownermanagers had direct access to the president of Germania Fairs.

Interestingly, the relationship between Granado and LBM seemed less asymmetric, despite size differences, probably because of the long-standing tradition of Granado in the Brazilian market. There is extraordinary value in firm and brand longevity, and LBM's management certainly recognized it. In addition, the relationship was based on transparency, at least on the side of Granado's management, who revealed to the partner the firm's future plans to open its own stores.

Nevertheless, in both cases the importance of the Brazilian partners was minor for the foreign partner, while the foreign partners were of major importance for the domestic firms, particularly in the case of Eco Orbis. Accordingly, there was dominant foreign partner control of the relationship (Christoffersen, 2013).

\section{Final status of the alliance}

Of the two marketing alliances examined, one had terminated (Eco Orbis and Germania Fairs) and the other was still going at the time of the study (Granado and LBM). In the former case, the alliance was seen as positive in its overall balance, as it allowed Eco Orbis to consolidate its business and develop a new activity - the organization of fairs and events. Nearly a decade of alliance duration was considered a satisfactory period. However, it caused frustration due to the expectation of continuity, which was disturbed by subsequent events: the acquisition of the business that became a subsidiary of Germania Fairs in Brazil, and the conflicts with GFB's new board. These events led the partners to believe that there was a major risk of Eco Orbis losing its business without any sort of compensation.

Thus, the decision was made to terminate the contract. Since the contract did not establish clear rules or indemnities in the case of cancellation, the alliance termination was detrimental to Eco Orbis, whose management had failed to foresee the possibility of a conflictual end to the relationship (Hamel, Doz \& Prahalad, 1989).

One has to wonder if dissimilarities between Eco Orbis and Germania Fairs were involved in the final situation of the alliance. According to Christoffersen (2013), only differences in size and national culture show repeated evidence in the literature of having a negative impact on the success of strategic alliances. In this case, both factors existed; not only was there an immense difference in size, but also a difference in terms of cultural background (Brazilian and German) of the firms. 
As for the alliance between Granado and LBM, which had endured for five years, it was not as critical for the Brazilian firm as in the previous case.

To a large extent, the benefits of the alliance were already being felt, since its major impact was on the positioning and reputation of the Granado brand in the foreign market, opening up several possibilities to forge ahead in international markets. In fact, Tiwari, Sen and Shaik (2016) claim that one of the major advantages of strategic alliances for emerging market firms is the possibility of overcoming liabilities of foreignness and lack of international branding, by associating with a well-positioned brand in a foreign market. This was exactly what the alliance brought to
Granado. Moreover, the alliance was not restrictive of Granado's further expansion in Paris, France, or in Europe. Lastly, the two firms were centennial, familyowned and family-managed (at least to some extent, in the case of LBM), and the differences in size were not as striking.

Finally, the fact that the owner-manager of the Brazilian firm is an Englishman may have reduced perceived liabilities of foreignness. Similarly, the minority stake held by the Puig group in Granado, although it happened when the alliance was already operational, might also have had a positive influence in terms of providing legitimacy. Figure 2 summarizes the findings of the study.

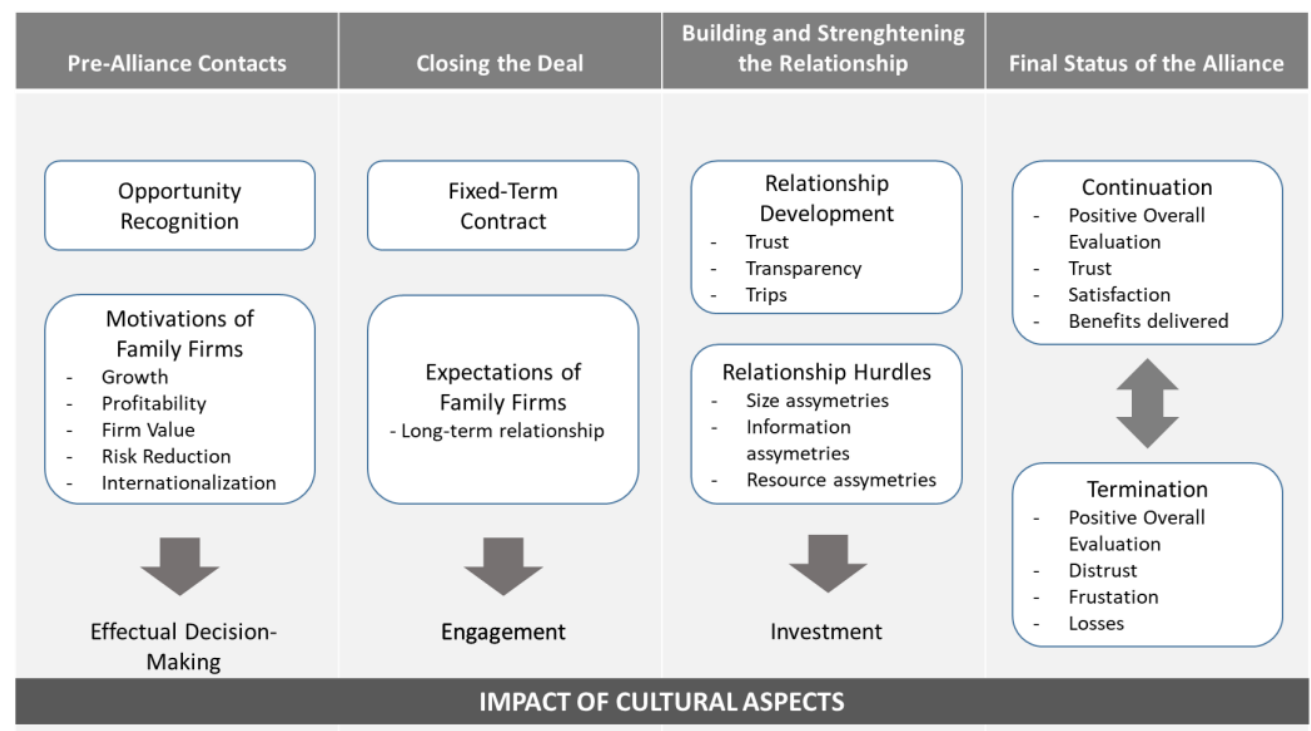

Figure 2: The Alliance Development Process

\section{Final Considerations}

The present study describes and analyzes two cases of strategic alliances between Brazilian family firms and foreign firms from developed economies. Although the method does not allow for generalizations to other strategic alliances, it allows for analytical generalizations, which may be tested in future studies.

In this study, strategic marketing alliances with international firms have helped the Brazilian family firms studied to go international. Moreover, they substantially helped the nascent entrepreneurial firm to establish itself with a new and highly visible product in the domestic market. In addition, the study highlights the role of trust and transparency for Brazilian family firms in relation to their international partners. Although the literature on networks and on strategic alliances has consistently pointed out the importance of trust (e.g. Forsgren \& Johanson, 1992; Bengoa \& Kaufmann, 2016), this study supports these findings in the context of an emerging market.

In spite of this, in one of the cases examined, the large multinational firm made a decision that would have a tremendous impact on the partner, but the partner only became aware of it after the fact, thus creating a distrustful environment for the alliance, with the perception that the larger partner had a "hidden agenda" (Bengoa \& Kaufmann, 2016).

However, the use of strategic alliances should not be considered a panacea. As mentioned by Miles, Preece \& Baetz (1999), smaller firms may face the dangers of dependence, as observed in one of the cases examined.

The study contributes to the literature on the internationalization of family firms, particularly on 
"Good While It Lasts": International Alliances Between Brazilian Family Firms And Foreign Firms

the use of strategic alliances as a mode for entering international markets by small and medium-sized emerging market firms, responding to a call in this literature (Ray, Mondal \& Ramachandran, 2018). The study offers an empirically-derived framework of the processes of establishing, developing, and (eventually) terminating these strategic alliances, indicating potential hazards (asymmetries of size, information, and resources) that can impact the results, particularly within a context of different cultural background of the partners.

There is another stream of studies on symbiotic asymmetric relationships, which portrays the advantages and disadvantages of associations, formal or informal, between smaller domestic firms and multinationals (e.g Coviello, 2006; Etemad, Wright \& Dana, 2001; Gabrielsson \& Kirpalani, 2004). This literature typically does not focus the family firm. Therefore, the present study also contributes to this literature, by examining the ways by which these relationships may develop in time when one of the parties is a small or medium-sized family firm from an

\section{References}

Arranz, N., Arroyabe, M. F., \& De Arroyabe, J. C. (2016). Alliance-building process as inhibiting factor for SME internationalization. British Journal of Management, 27, 497-515.

Arregle, J.L., Duran, P., Hitt, M.A., \& Essen, M. (2017). Why is family firms' internationalization unique? A metaanalysis. Entrepreneurship: Theory \& Practice, 41(5), 801831.

Barney, J. B., \& Hesterly, W. S. (2011). Administração estratégica e vantagem competitiva. São Paulo: Prentice Hall, 2011.

Beamish, P.W. \& Jung, J.C. (2005). The performance and survival of joint ventures with parents of asymmetric size. Management International, 10, 19-30.

Beamish, P. W., \& Lupton, N. C. (2016). Cooperative strategies in international business and management: Reflections on the past 50 years and future directions. Journal of World Business, 51(1), 163-175.

Bengoa, D.S., \& Kaufmann, H. R. (2016). The influence of trust on the trilogy of knowledge creation, sharing, and innovation. Thunderbird International Business Review, 58(3), 239-249.

Brenes, E.R., Madrigal, K., \& Requena, B. (2011). Corporate governance and family business performance. Journal of Business Research, 64(3), 280-285. emerging market, having to face liabilities of smallness, foreignness and emergingness. In addition to the academic contribution, reporting these experiences can be useful to family business leaders before and during the development of international alliances because it portrays the problems and opportunities faced in real business situations.

The study presents some limitations, besides those related to the research method adopted.

First, only two cases were analyzed, and both of them refer to strategic alliances between Brazilian firms located in Rio de Janeiro, Brazil, and foreign firms; thus, these experiences may differ from those of firms from other emerging markets, and even from other areas of Brazil. Second, we looked at these experiences only from the perspective of the smaller, domestic partner - an unusual perspective in the extant literature. Further research is needed to get a broader picture of strategic alliances between family firms from emerging markets and large firms from advanced economies.

Christoffersen, J. (2013). A review of antecedents of international strategic alliance performance: Synthesized evidence and new directions for core constructs. International Journal of Management Reviews, 15(1), 66-85.

Coviello, N. (2006). The network dynamics of international new ventures. Journal of International Business Studies, 37, 713-731.

De Massis, A., Frattini, F., Majocchi , A., \& Piscitello, L. (2018). Family firms in the global economy: Toward a deeper understanding of internationalization determinants, processes, and outcomes. Global Strategy Journal, 8(1), 3-21.

De Wit, B., \& Meyer, R. (2004). Strategy - Process, Content and Context: An International Perspective ( $3^{\text {rd }}$. Ed.). London: Thomson Learning.

Dou, J., Jacoby, G., Li, J., Su, Y., \& Wu, Z. (2019). Family involvement and family firm internationalization: The moderating effects of board experience and geographical distance. Journal of International Financial Markets, Institutions and Money, 59, 250-261.

Doz, Y.L. (1988). Technology partnerships between larger and smaller firms: some critical issues. In: Contractor, F.J., \& Lorange, P. (eds.), Cooperative strategies in international business. Lexington, KY, Lexington Books, p. 317-328.

Etemad, H., Wright, R.W., \& Dana, L.P. (2001). Symbiotic international business networks: 
collaboration between small and large firms. Thunderbird International Business Review, 43(4), 481499.

Forsgren, M., \& Johanson, J. (1992).Managing networks in international business. Philadelphia, Gordon and Breach.

Gabrielsson, M., \& Kirpalani, V.H.M. (2004). Born globals: how to reach new business space rapidly. International Business Review, 13(5), 555-571.

Gernier, J. (2011). LVMH lance Le Bon Marché dans un chantier titanesque. La Tribune, December 8. Retrieved from http://www.latribune.fr

Ghauri, P. (2004). Designing and conducting case studies in international business research. In: MarschanPiekkari, R., \& Welch, C. (eds.), Handbook of Qualitative Research Methods in International Business. Cheltenham, UK: Edward Elgar, pp. 109-124.

Gomes, E., Barnes, B., \& Mahmood, T. (2016). A 22year review of strategic alliance research in the leading management journals. International Business Review, 25, 15-17.

Hamel, G., Doz, Y., \& Prahalad, C. (1989). Collaborate with your competitors and win. Harvard Business Review, (January-February), 133-139.

IBGC - Instituto Brasileiro de Governança Corporativa (2016). Governança da Família Empresária: Conceitos Básicos, Desafios e Recomendações. São Paulo: IBGC.

Johanson, J., \& Vahlne, J.-E. (2009). The Uppsala internationalization process model revisited: From liability of foreignness to liability of outsidership. Journal of International Business Studies, 40(9), 1411-1431.

Johanson, J., \& Vahlne, J.-E. (2013). The Uppsala model on evolution of the multinational business enterprise from internalization to coordination of networks. International Marketing Review, 30 (3), 189-210.

Kontinen, T., \& Ojala, A. (2010). The internationalization of family businesses: A review of extant research. Journal of Family Business Strategy, 1(2), 97-107.

Lee, H., Kelley, D., Lee. J., \& Lee, S. (2012). SME survival: The impact of internationalization, technology resources and alliances. Journal of Small Business Management, 50 (1), 1-19.

López-Fernandez, M. C., Serrano-Bedia, A.M., \& Pérez-Pérez, M. (2016). Entrepreneurship and family firms: a bibliometric analysis of an emerging field. Journal of Small Business Management, 54(2), 622-639.
Marín-Anglada, Q., Campa-Planas, F. \& HernándezLara, A. B. (2014). Uncertainty in the family business facing the process of internationalization: Literature review and future research agenda. Intangible Capital, 10(4), 836-853.

Mehta, R., Polsa, P., Mazur, J., Xiucheng, F. , \& Dubinsky, A. J. (2006). Strategic alliances in international distribution channels. Journal of Business Research, 59 (10), 1094-1104.

Miles, G., Preece, S. B. \& Baetz, M. C. (1999). Dangers of dependence: The impact of strategic alliance use by small technology-based firms Journal of Small Business Management, 37 (2), 20-29.

Musteen, M., \& Datta, D.K. (2011). Learning about foreign markets: A study of Czech SMEs. Journal of International Entrepreneurship, 9(2), 91-109.

Oliveira, J. L., Albuquerque, A.L., \& Pereira, R.D. (2012). Governança, sucessão e profissionalização em uma empresa familiar: (re)arranjando o lugar da família multigeracional. Revista Brasileira de Gestão de Negócios, 14(43), 176-192.

Patel V. K., Pieper T. M., \& Hair J. F. (2012). The global family business: Challenges and drivers for cross-border growth. Business Horizons, 55, 231-239.

Piekkari, R., \& Welch,C. (2011). Pluralism in international business and international management research: making the case. In Marschan-Piekkari, R., \& Welch, C. (eds.), Retinking the Case Study in International Business and Management Research. Cheltenham, UK: Edward Elgar, p. 3-23.

Pukall, T. J., \& Calabrò, A. (2014). The internationalization of family firms: A critical review and integrative model. Family Business Review, 27(2), 103125.

PWC - PricewaterhouseCoopers Brasil (2016). Pesquisa Global sobre Empresas Familiares 2016. Available at https://www.pwc.com.br/pt/estudos/setoresatividade/pcs/2017/pesquisa-global-empresasfamiliares-2016.html

Ray, S., Mondal, A., \& Ramachandran, K. (2018). How does family involvement affect a firm's internationalization? An investigation of Indian family firms. Global Strategy Journal, 8(1), 73-105.

Saravasthy, S.D. (2001). Causation and effectuation: towards a theoretical shift from economic inevitability to entrepreneurial contingency. Academy of Management Review, 26(2), 243-288. 
"Good While It Lasts": International Alliances Between Brazilian Family Firms And Foreign Firms

Sciascia, S., Mazzola, P., Astrachan, J. H., \& Pieper, T. M. (2012). The role of family ownership in international entrepreneurship: Exploring nonlinear effects. Small Business Economics, 38(1), 15-31.

Sebrae (2015). Feiras de Negócios agitam as oportunidades no país. Brasil. Available at: $<$ http://www.sebraemercados.com.br/2015-feiras-denegocios-agitam-as-oportunidades-no-pais $>$.

Segalis, G., \& Guedes, A. L. M. (2012). Internacionalização de empresas familiares de pequeno e de médio portes. Revista ADM.MADE, 16(3), 37-59.

Swaminathan, V. \& Moorman, C. (2009). Marketing alliances, firm networks, and firm value creation. Journal of Marketing, 73(5), 52-69.

Tiwari, S.K., Sen, S. and Shaik, R. (2016). Internationalization: A study of small firms from emerging markets. The Journal of Developing Areas, 50(6), 355-364.

Varadarajan, P.R., \& Cunningham, M.H (1995). Strategic alliances: a synthesis of conceptual foundations. Journal of the Academy of Marketing Science, 23, 282-296.

Yamanoi, J., \& Asaba, S. (2018). The impact of family ownership on establishment and ownership modes in foreign direct investment: The moderating role of corruption in host countries. Global Strategy Journal, 8(1), 106-135.

Yin, R. K. (2015). Estudo de Caso - Planejamento e Métodos (5a Ed.). Porto Alegre: Bookman.

Yu, J., Gilbert, B.A., \& Oviatt, B. M. (2011). Effects of alliances, time, and network cohesion on the initiation of foreign sales by new ventures. Strategic Management Journal, 32 (4), 424-446.

\section{ABOUT AUTHORS}

- Álvaro Luiz dos Santos Werneck - Pontifícia Universidade Católica do Rio de Janeiro - PUC, Rio de Janeiro, (Brasil). E-mail: alvaro.werneck@gmail.com Orcid id: https://orcid.org/0000-0003-4943-4312

- Ângela da Rocha - Pontifícia Universidade Católica do Rio de Janeiro, IAG Escola de Negócios, Rio de Janeiro, (Brasil). E-mail: amc.darocha@gmail.com Orcid id: https://orcid.org/0000-0001-6651-0933 
217

\title{
"BOM ENQUANTO DURA": ALIANÇAS INTERNACIONAIS ENTRE EMPRESAS FAMILIARES BRASILEIRAS E EMPRESAS ESTRANGEIRAS
}

\author{
Álvaro Luiz dos Santos Werneck, Ângela da Rocha \\ Pontifícia Universidade Católica do Rio de Janeiro - PUC, Rio de Janeiro, (Brasil).
}

\begin{tabular}{l}
\hline DETALHES DO ARTIGO \\
\hline Histórico do Artigo: \\
Recebido em: 26 de setembro de 2018 \\
Aceito: 03 de junho de 2019 \\
Disponível online: 01 de agosto de \\
2019 \\
Sistema de revisão “Double blind \\
review” \\
Editor Científico \\
Ilan Avrichir \\
\hline Palavras-Chave \\
Alianças \\
Parcerias \\
Estratégias Cooperativas
\end{tabular}

\section{RESUMO}

O estudo teve como objetivo pesquisar como as empresas familiares brasileiras se internacionalizam por meio de alianças estratégicas com empresas estrangeiras. Uma revisão de literatura sobre alianças estratégicas e a internacionalização de empresas familiares serviu de base para o estudo, que utiliza estudo de caso como método. Dois casos envolvendo alianças de marketing entre empresas familiares brasileiras e empresas estrangeiras foram analisados. O estudo apresenta um framework derivado empiricamente dos processos de estabelecer, desenvolver e (eventualmente) terminar essas alianças estratégicas, indicando possíveis riscos (assimetrias de tamanho, informação e recursos) que podem impactar os resultados, particularmente dentro de um contexto de diferentes origens culturais dos parceiros.

\section{Cite it like this:}

Werneck, A., \& da Rocha, A. (2019). "GOOD WHILE IT LASTS": INTERNATIONAL ALLIANCES BETWEEN BRAZILIAN FAMILY FIRMS AND FOREIGN FIRMS. Internext, 14(3), 204-217. doi:http://dx.doi.org/10.18568/internext.v14i3.474 